\title{
Könyvszemle
}

SIPOS JÚLIA GONDOZÁSÁBAN

\section{A RENESZÁNSZ GYERMEKKÉPE. A GYERMEKKÉP RENESZÁNSZA 1455-1517 KÖZÖTT EURÓPÁBAN}

A könyv Endrődy-Nagy Orsolya 2015-ben sikeresen megvédett doktori (PhD) disszertációjának megjelentetése a Takács Etel Pedagógiai Alapítvány kuratóriuma könyvsorozatában, mely szervezet kiadványai által értékes szakdolgozatok és - ahogy adott esetben is - doktori disszertációk kerülhetnek a szélesebb szakmai közösség és érdeklődő olvasók elé. A szerző interdiszciplináris keretek között mikrotörténeti perspektívából kívánja bemutatni, értelmezni a korszak gyermekképét a neveléstudomány, gyermekkortörténet, a képzőmüvészeti alkotások beépítése a művészettörténet segédtudományával, azaz az ikonográfiai elemzés segítségével. Hazánkban csak kis számban születtek még olyan kutatások, melyek a képeket a neveléstörténeti vizsgálódásokba korszakokra bontva, tematikusan integrálják, használják elsődleges forrásként (például: Géczi János, Kéri Katalin vagy Mikonya György munkái, melyekröl részletes bibliográfiai adatokat a diszszertáció irodalomjegyzékében találhatunk). A vizsgált időintervallum az 1440es évektől az 1520-as évekig tart, mely kijelölt időszak segít a müvészettörténetileg háromszáz éves időszakra nyúló reneszánsz kort rövidebb egységekre osztani, ezzel pontosítani, árnyalni a reneszánsz gyermekképét.

Endrődy-Nagy Orsolya azt az alaptézist fektette le írása megszületésénél, hogy a képzőmủvészeti alkotások reprezentációi lehetnek a történelemnek, kiegészíthetik, tisztázhatják, színesíthetik az egyes múltbéli eseményeket. Adott esetben tehát a fő cél a reneszánsz kor gyermekképének egy sajátos metodológiával való kutatása. A szerző írásában kiemeli, hogy a képtípusok a neveléstörténeti kutatások elsődleges forrásai közé illeszthetők be, és ezzel élve, az egyes képeket önálló, feldolgozható, elemezhető forrásként tekinti, mint egyfajta narratívákat: „A képeket nem pusztán látjuk, hanem olvassuk” (50.). Ám neveléstörténészként a célja nem a mủvészettörténeti elemzés, hanem a nevelési szokások, a korszak gyermekképének feltárása. Nagyon fontos kihangsúlyozni, hogy az egyes képek elemzése a szerző saját interpretációjának tekinthető, nem pedig abszolút érvényű általánosításra törekvésnek. Ez azt jelenti, hogy többféle igazság alkotható, amit a könyvben olvasunk, az egyfajta megközelítésmód, értelmezési mód. 
Kiemelendő, hogy a téma és főként a metodológia újdonsága miatt a szerző nagyon alapos szakirodalmi áttekintést végez a témában megjelent irodalmak, elméleti-módszertani támpontok, az ezek közötti összefüggések keresésének tekintetében. A vizsgálat a kvalitatív kutatások közé tartozik, melynek lényege nem az eredmények számszerüsítése, hanem az értelmezésen, az összefüggések keresésén van a hangsúly. Többféle értelmezést tesz lehetővé, „mélyfúrásokat” végez. Endrődy-Nagy Orsolya disszertációjában különböző technikával készült képek kvalitatív elemzésére vállalkozott, a képi és írásos dokumentumokat, forrásokat együtt használta a kutatása során, mely érvényességet biztosít a kutatási eredmények validitását tekintve.

Fontosnak tartom ismertetni a szerző metodológiáját, mely egy nem elterjedt, egyedi eljárásmódnak tekinthető a neveléstörténeti diszciplínán belüli kutatásokat tekintve. A szerző Colin Heywood angol neveléstörténész 2001-es írása alapján - részletezve és kiegészítve azt - a következő témákat vette szemügyre elemzése során az egyes képeken: születés (fogantatás és terhesség, szülés, császármetszés); a csecsemők élete (szoptatás, pólyázás, tisztaság); betegség és halál (gyermekhalandóság, a halálhoz való viszony). Ezenkívül a játék témakörének vizsgálata is megjelent Endrődy-Nagy vizsgálódásában, bár szembetünően rövidebben kifejtve a többihez képest. A képelemzések során négy fő lépést tartott be, illetve ezeket ötvözve hozta létre elemző metódusát a szerző minden egyes feltárandó témán belül. Az első lépésként minden esetben az ikonográfia atyjának tekinthető Erwin Panofsky módszerét alkalmazta, melyen belül a preikonografikus (érzéki tapasztalatok) és ikonografikus (jelentésértelem) elemzést tette meg. Másodsorban a francia Olivier Bouteaud-féle módszert használta, mely a technikára fókuszál. Ám a technikai részleteken kívül fontos másfajta nézőpontok bevonása is a képelemzés folyamatába, például az adott társadalmi kontextus, a háttérinformációk, a kép keletkezési körülményeinek figyelembevétele. Ezt figyelembe véve a szerző Panofsky módszerébe ágyazva alkalmazza Bouteaud kódrendszerét, és a végén alkotja meg a mélyebb összefüggéseket tartalmazó ikonológiai szintézist. Végül az egyes fejezetekben vizsgált képeket tematikai hasonlóság alapján a vizuális antropológiából adaptált Malcolm Collier-féle sorozatelemzésekkel veti össze az összefüggések keresése érdekében, és mindezek után von le következtetéseket a képanyagra vonatkozóan. A képeken megjelenő gyermekképet többféle összehasonlítással vizsgálja. Többek közt arra is kíváncsi, mennyiben különböznek a különböző technikával készült alkotások egymáshoz viszonyítva (például a miniatúrákon ábrázolt gyermekek az ősnyomtatványok gyermekképétől; illetve az orvosi könyvek és festmények közötti hasonlóságok-különbségek is vizsgálódásának fókuszába helyezhetők).

A reneszánsz kor gyermekfelfogására jellemzőnek mondhatjuk, hogy bár változást hozott a középkori gyermekfelfogásban, és a reneszánsz humanistái (például Erasmus, Montaigne) kihangsúlyozták, hogy a gyermekkor az ártatlanság kora, a 
gyerekek erkölcsi nevelésre szorulnak, elvetették a testi fenyítést, viszont a mindennapok gyakorlatában ez az újfajta, gyermeket felfedező és értékelő szemlélet nem igazán vált valóra. A disszertáció témájának érdekességét tehát az is adhatja, hogy a reneszánsz kor adott időszakának vizsgálatával a képzőmủvészek által megjelenített gyermekképről kaphatunk információt, ezzel összevethetővé válik a korábbi írott elsődleges és másodlagos forrásokban olvasható gyermekképpel.

A disszertáció értékei közé tartozik a téma és a metodológia egyedisége, interdiszciplináris jellege. Ez az újdonság, egyediség a téma további kibontását is magában hordozza, amit a szerző a disszertáció záró szakaszában ki is fejt. Kiemeli például, hogy neveléstörténeti szöveggyüjtemények mellett hasznos lehet képgyüjtemények megjelentetése is, melyekkel akár az oktatói módszertani repertoár is bővülhetne, ha a hallgatók e képgyüjtemények segítségével tanulnának különböző korszakok gyermekképéről. Illetve a disszertációban olvasottak mintájára más korszak gyermekfelfogását is lehetne kutatni, a szerző tervei között szerepel is a japán-amerikai-magyar gyermekkép összehasonlítása. Ezenkívül értékként a széles nemzetközi elsődleges és másodlagos források felhasználása is kiemelendő, ami megmutatkozik például a feldolgozott képanyagok felkutatásának helyszíneiben is (feltárási helyszíneket lásd 99.). Ide kapcsolódóan Endrödy-Nagy kiemeli, hogy a képanyagok elemzésén kívül fontos kiaknázatlan forrást jelenthetnek egy-egy adott korszak mesekönyvei vagy a 20. századtól a rajzfilmjei. Láthatjuk tehát, hogy több újszerủ kutatási téma is tárt karokkal várja, többek között, az érdeklődő neveléstörténészeket.

(Endrödy-Nagy Orsolya: A reneszánsz gyermekképe. A gyermekkép reneszánsza 1455-1517 között Európában. Ikonográfiai elemzés. Doktori (PhD) disszertáció. (TEPA Könyvek) Budapest: Eötvös Kiadó, 2015)

Balog Beáta

doktorjelölt Eötvös Loránd Tudományegyetem Pedagógiai és Pszichológiai Kar Neveléstudományi Intézet Neveléstudományi Doktori Iskola Történeti, Elméleti és Összehasonlító Pedagógiai Kutatócsoport 